\title{
Chemical constituents from the stem of Brosimum potabile (Moraceae)
}

\author{
Viviane Gomes da Costa ABREU ${ }^{1}$, Marilda Conceição da SILVA², Rozângela Manfrini MAGALHÃES³, \\ Dorila PILÓ-VELOSO ${ }^{4}$, Izelene Felício da Silva XAVIER ${ }^{5}$, Patrícia Machado OLIVEIRA ${ }^{6}$, Antônio Flávio de \\ Carvalho ALCÂNTARA ${ }^{7}$
}

\begin{abstract}
Three coumarins, 5-methoxypsoralene, xanthyletin, and (-)-marmesin, have been isolated from the ethanolic extract of the stem of the Amazonian plant Brosimum potabile. The structures were determined on the basis of NMR analyses and by comparison with spectroscopic data in the literature. The analysis of the hexane fractions by GC-MS in EIMS mode suggested the presence of (1-methylpentyl)-benzene; $\alpha, \alpha$-dimethyl-4-(1-methylethyl)-benzenemethanol; 1-methyl-3,5-bis(1-methylethyl)benzene; urs-12-ene; chola-5,22-dien-3 $\beta$-ol; cholesta-4,6-dien-3 $\beta$-ol; sitosteryl $9(Z$ )-octadecenoate; cholesta-5,22-dien-3 $\beta$-ol; cholesta-4,6,22-trien-3-one; and cholesta-4,22-dien-3-one. NMR data of other hexane fractions indicated the presence of $3 \beta$-acetoxy-lup-12,20(29)-diene; $3 \beta$-acetoxy-olean-12-ene; $3 \beta$-acetoxy-urs-12-ene; and adian-5-ene. All these compounds are first described in $B$. potabile.
\end{abstract}

KEYWORDS: Brosimum potabile, coumarins, pentacyclic triterpenes, structural characterization by NMR and GC/MS.

\section{Constituintes químicos do cerne de Brosimum potabile (Moraceae)}

\section{RESUMO}

Três cumarinas, 5-metoxipsoraleno, xantiletina e (-)-marmesina, foram isoladas no extrato etanólico do cerne da planta amazônica Brosimum potabile. Suas estruturas foram determinadas a partir das análises por RMN e por comparação com dados espectroscópicos da literatura. As análises das fraçóes hexânicas por CG/EM sugeriram a presença de (1-metilpentil)-benzeno; $\alpha, \alpha$-dimetil-4-(1-metiletil)-benzenometanol; 1 -metil-3,5-bis(1-metiletil)-benzeno; urs-12-eno; cola-5,22-dien-3 $\beta$-ol; colesta4,6-dien-3 $\beta$-ol; (9Z)-octadecenoato de sitosterila; colesta-5,22-dien-3 $\beta$-ol; colesta-4,6,22-trien-3-ona e colesta-4,22-dien-3-ona. Dados de RMN de outras fraçóes hexânicas indicaram a presença de $3 \beta$-acetóxi-lup-12,20(29)-dieno; $3 \beta$-acetóxi-olean-12-eno; $3 \beta$-acetóxi-urs-12-eno e adian-5-eno. Todos esses compostos foram identificados pela primeira vez em B. potabile.

PALAVRAS-CHAVE: Brosimum potabile, cumarinas, triterpenos pentacíclicos, caracterização estrutural por RMN e CG/EM.

\footnotetext{
1 Departamento de Química, ICEx, Av. Antônio Carlos, 6627 - Pampulha - Belo Horizonte - MG CEP 31270-901, E-mail: vgcabreu@yahoo.com.br

2 Departamento de Química, ICEx, Av. Antônio Carlos, 6627 - Pampulha - Belo Horizonte - MG, E-mail: marsi_br@yahoo.com.br

${ }^{3}$ Departamento de Química, ICEx, Av. Antônio Carlos, 6627 - Pampulha - Belo Horizonte - MG, E-mail: romanfrini@yahoo.com.br

${ }^{4}$ Departamento de Química, ICEx, Av. Antônio Carlos, 6627 - Pampulha - Belo Horizonte - MG, E-mail: dorila@zeus.qui.ufmg.br

${ }^{5}$ Departamento de Química, ICE, AV. General Rodrigo Octávio Jordão Ramos, 3000 - Coroado, E-mail: izelenefsx@yahoo.com.br

${ }^{6}$ Departamento de Química, FACET, Campus JK, Rodovia MGT 367 - Km 583, nº 5000 Alto da Jacuba, Diamantina/MG, E-mail: patricia.oliveira@ufvjm.edu.br

7 Universidade Federal de Minas Gerais, Departamento de Química, ICEx, Av. Antônio Carlos, 6627 - Pampulha - Belo Horizonte - MG, CEP $31270-901$ E-mail: aalcantara@zeus.qui.ufmg.br
} 


\section{INTRODUCTION}

Plants of the Brosimum (Moraceae) (Oliveira and Amaral 2004) genus are largely found in firm land regions of the Amazon forest (Correia 1978). Extracts from stem bark of Brosimum species, which are used as a nervous system stimulant in folk medicine, have also shown anti-syphilic, anti-inflammatory, and antirheumatic activities (Garret and Grishan 1988, Shultes and Foreword 1992). Several chemical compound classes have been isolated from Brosimum species: flavans (Torres et al. 1997; Teixeira et al. 2000), steroids, coumarins (Okahara 1936, Gottlieb et al. 1972), terpenes, benzophenone, xantones, tannins, saponines, alkaloids, and polyphenols (Filho et al. 1972). Brosimum potabile is popularly known as "amapá-doce" and largely used in Amazon region as medicinal extract (Berg 1972, Barroso 1978). But only few studies have been described about this species. We have previously investigated extract of its stem and 1-diarilheptanoid (centrolobin), sitosterol, and stigmasterol were isolated (Alcântara et al. 2000).

In the present work we described a more exhaustive phytochemical investigation of the stem of Brosimum potabile. As consequence 17 compounds were characterized by IV, NMR (1D and 2D), and GC/MS analyses which were firstly described in this species.

\section{PHYTOCHEMICAL PROCEDURE}

\section{General methods}

Uncorrected melting points were determined using METTLER equipment, model FP82. FTIR spectra were determined in $\mathrm{KBr}$ disk on a FTIR Perkin Elmer Spectrum 200 spectrometer. GC/MS spectra were obtained on a Perkin Elmer - Auto System chromatographer coupled to a Perkin Elmer - Q-Mass 910 mass spectrometer $(70 \mathrm{eV}, 30 \mathrm{~m} / 0.2$ $\mathrm{nm}$ methyl silicone fused silica column, helium gas, draw speed: $1.5 \mathrm{~mL} / \mathrm{min}$ ). The sample components were identified based on software comparison of mass spectra fragmentation patterns with those of the Wiley Library Database Version 2005 (New York, USA). Retention time (RT) is given in minutes. Chromatographic purification was carried out on silica gel (70-230 Mesh), alumina, and Sephadex LH-20. A mixture of silica gels $60 \mathrm{~F}_{254}$ and $60 \mathrm{G}(1: 3)$ was used in thin layer chromatographic analysis.

${ }^{1} \mathrm{H}$ and ${ }^{13} \mathrm{C}$ NMR spectra were measured on a Bruker DRX 400 - AVANCE spectrometer, with inverse probes and field gradient operating at 400.129 and $100.613 \mathrm{MHz}$, respectively. The samples were dissolved in $0.75 \mathrm{~mL} \mathrm{CDCl}_{3}$ and transferred to a $5-\mathrm{mm}$ NMR tube; TMS was used as an internal reference $(\delta=0.00)$. Chemical shifts are given in the $\delta$-scale (ppm) and coupling constants, $J$, in Hz. Experiments were carried out using pulse sequences and programs provided by the manufacturer. One-dimensional (1D) ${ }^{1} \mathrm{H}$ and ${ }^{13} \mathrm{C}$ NMR spectra were acquired under standard conditions by using a direct detection $5-\mathrm{mm}{ }^{1} \mathrm{H} /{ }^{13} \mathrm{C}$ dual probe. Standard pulse sequences were used for two-dimensional (2D) homonuclear and heteronuclear shift correlation spectra by using a multinuclear, inverse detection, 5-mm probe with field gradient at $\mathrm{z}$ axis.

\section{Plant material}

A Brosimum potabile sample was collected in November 1999 at the Adolpho Ducke Reserve, Manaus, Brazil. A voucher specimen of Brosimum potabile has been deposited at the herbarium of the Instituto Nacional de Pesquisas da Amazônia (INPA-Manaus), under the code 105.994. The plant was identified by S. S. da Silva (Departamento de Botânica, Universidade Federal do Amazonas) and later confirmed by Dr. J. E. L. da Silva and C. A. C. Ferreira (Departamento de Botânica, Herbário do INPA).

\section{Extraction and isolation}

The collected plant was dried at room temperature and triturated. The powered material $(2.4 \mathrm{~kg})$ was submitted to extraction in hexane and $\mathrm{EtOH}$ at room temperature, furnishing hexanic $(\mathrm{EH} ; 100.5 \mathrm{~g})$ and ethanolic (EE; 430.0 g) extracts, respectively. $\mathrm{EH}$ was submitted to column chromatography (CC) using silica gel as the stationary phase (CCS) and eluted with hexane, $\mathrm{CH}_{2} \mathrm{Cl}_{2}$, EtOAc, $\mathrm{EtOH}$, and $\mathrm{MeOH}$ mixtures in increasing polarity order. The chromatographic fractionation of EH was followed by thin layer chromatography (TLC) and similar fractions were grouped. Group 3 (eluted with hexane) was obtained as a colorless liquid $(6 \mathrm{mg}$ ) and identified as mixture of 1 to 3 . Group 7 (eluted with hexane and dichloromethane 9:1) was submitted to CCS fractionation eluted with hexane $/ \mathrm{CH}_{2} \mathrm{Cl}_{2}$ in gradient. The fraction eluted with hexane/ $\mathrm{CH}_{2} \mathrm{Cl}_{2}(8: 2)$ was recrystallized in $\mathrm{EtOH}$, afforded a white solid (compound 4, $3 \mathrm{mg}$ ). Group 8 (eluted with hexane $/ \mathrm{CH}_{2} \mathrm{Cl}_{2}$ 6:4) was rechromatographed in silica gel with a gradient hexane/ $\mathrm{CH}_{2} \mathrm{Cl}_{2}$. The fractions obtained with hexane/ $\mathrm{CH}_{2} \mathrm{Cl}_{2} 7: 3$ were recrystallized in EtOH yielded a white solid $(21 \mathrm{mg})$ identified as a mixture of compounds $\mathbf{5}$ to $\mathbf{8}$.

Group 11 (eluted hexane/ $\mathrm{CH}_{2} \mathrm{Cl}_{2}$ ) was submitted to CCS fractionation eluted with hexane $/ \mathrm{CH}_{2} \mathrm{Cl}_{2}$ in gradient. The fractions eluted with $\mathrm{CH}_{2} \mathrm{Cl}_{2}$ were recrystallized in $\mathrm{EtOH}$, providing a white solid ( $7 \mathrm{mg}$ ) identified as a mixture of compounds 9 to 13. Group 13 (eluted with $\mathrm{CH}_{2} \mathrm{Cl}_{2} / \mathrm{EtOAc}$ 9.5:0.5) was submitted to CCS fractionation eluted with hexane $/ \mathrm{CH}_{2} \mathrm{Cl}_{2}$ in gradient. The fractions obtained with $\mathrm{CH}_{2} \mathrm{Cl}_{2}$ were purified by recrystallization in $\mathrm{EtOH}$, afforded a white solid (3 mg) identified as compound 14. EE was submitted to CCS fractionation eluted with hexane, $\mathrm{CH}_{2} \mathrm{Cl}_{2}$, EtOAc, EtOH, and $\mathrm{MeOH}$ mixtures in increasing polarity. 
The chromatographic fractionation of EE was followed by TLC and similar fractions were grouped. Group 2 was eluted in $\mathrm{CH}_{2} \mathrm{Cl}_{2}$, providing a white solid. This solid was submitted to CCS and eluted with gradient of hexane $/ \mathrm{CH}_{2} \mathrm{Cl}_{2}$. Fractions obtained with hexane/ $\mathrm{CH}_{2} \mathrm{Cl}_{2}$ 3:7 were grouped and recrystallized in hexane, yielded a white solid $(18 \mathrm{mg})$ identified as compound $\mathbf{1 5}$. Group 5 (eluted with $\mathrm{CH}_{2} \mathrm{Cl}_{2}$ ) afforded a light yellow solid after washing with $\mathrm{MeOH}$ (compound 16, $45.7 \mathrm{mg}$ ). Group 8 (eluted with $\mathrm{CH}_{2} \mathrm{Cl}_{2} /$ EtOAc 1:1) was submitted to CC using Sephadex LH-20 as a stationary phase and $\mathrm{MeOH}$ as eluent. Fractions 8 and 9 were grouped and submitted to $\mathrm{CC}$ using neutral alumina as the stationary phase and eluted with $\mathrm{CH}_{2} \mathrm{Cl}_{2}$ afforded a white solid (Compound 17, $5.7 \mathrm{mg}$ ).

Mixture of compounds 1 to 3: (1-methylpentyl)-benzene, $\alpha, \alpha$-dimethyl-4-(1-methylethyl)-benzenemethanol, and 1-methyl-3,5-bis(1-methylethyl)-benzene, respectively. GC/ MS (EI, $70 \mathrm{eV}$ ) RT $=3.42 \mathrm{~min}, \mathrm{~m} / \mathrm{z} 162\left[\mathrm{M}^{+}\right], 105$ (base peak), 91, 77, 41, and 29; RT $=5.45 \mathrm{~min}, \mathrm{~m} / \mathrm{z} 178\left[\mathrm{M}^{+}\right], 163,145$, 121,105 , and 43 (base peak); RT $=9.16 \mathrm{~min}, \mathrm{~m} / \mathrm{z} 161,147$, $133,119,105,91,77$, and 43 (base peak).

Compound 4: urs-12-ene. GC/MS (EI, $70 \mathrm{eV}$ ) RT = $20.81 \mathrm{~min}, \mathrm{~m} / \mathrm{z} 498,406,392,296,218,203,191,179,165$, 151 (base peak), 133, 115, 84, and 58.

Mixture of compounds 5 to 8: $3 \beta$-acetoxy-lup-12,20(29)diene, $3 \beta$-acetoxy-olean-12-ene, $3 \beta$-acetoxy-urs- 12 -ene, and adian-5-ene, respectively. See Table 1 for NMR data.

Mixture of compounds 9 to 13: chola-5,22-dien-3 $\beta$ ol, cholesta-4,6-dien-3 $\beta$-ol, sitosteryl 9(Z)-octadecenoate, cholesta-5,22-dien-3 $\beta$-ol, and cholesta-4,6,22-trien-3-one, respectively. GC/MS (EI; $70 \mathrm{eV}$ ) RT $=24.40 \mathrm{~min}, \mathrm{~m} / \mathrm{z} 255$, 207, 189, 159 (base peak), 145, 131, 122, 119, 109, and 105; $\mathrm{RT}=25.81 \mathrm{~min}, \mathrm{~m} / \mathrm{z} 394,275,211,191,177,157,143$ (base peak), 135, 129, 119, and 105; RT = $26.02 \mathrm{~min}, \mathrm{~m} / \mathrm{z} 396$, 288, 275, 255, 213, 195, 177, 159, 147, 140 (base peak), 128,119 , and 105; RT $=28.20 \mathrm{~min}, \mathrm{~m} / \mathrm{z} 413,394,369,351$, 314, 300, 283, 271, 255, 213, 189, 173, 159, 147, 133, 119, 105 (base peak), 95, 81, 69, 55, and 41; RT = $29.05 \mathrm{~min}, \mathrm{~m} / \mathrm{z}$ $414,396,381,329,303,273,255,213,159,145,133,121$, $107,95,81,69,55$, and 43 (base peak); RT $=30.49 \mathrm{~min}, \mathrm{~m} / \mathrm{z}$ 270, 255, 227, 207, 175, 159, 147, 133, 119, 105, 95, 81. 69 (base peak), and 55.

Compound 14: cholesta-4,22-dien-3-one. GC/MS (EI; $70 \mathrm{eV}) \mathrm{RT}=3.62 \mathrm{~min}, \mathrm{~m} / \mathrm{z} 423,411,395,367,312,298$, $269,245,218,175,161,147,135,123,107$ (base peak), $95,81,69$, and 55 .

Compound 15: 5-methoxypsoralen. M.p.: 142.0-145.0 ${ }^{\circ} \mathrm{C} . \mathrm{IR}\left(\mathrm{KBr}, \mathrm{cm}^{-1}\right) v_{\max } 3220,3163,3151,3077,2955,1765$, 1593, 1494, 1366, 1180, 1058, 939, and 809. ${ }^{1} \mathrm{H}$ NMR (400 $\mathrm{MHz} ; \mathrm{CDCl}_{3}$; ppm) $\delta_{\mathrm{H}} 8.16(\mathrm{~d}, J=8.9 \mathrm{~Hz} ; \mathrm{H}-4), 7.60$ (d, J=
2.4 Hz; H-2'), 7.13 (s; H-8), 7.02 (d, J= 2.4 Hz; H-3'), 6.28 (d, J= $8.9 \mathrm{~Hz} ; \mathrm{H}-3), 4.30$ (s; H-2"). ${ }^{13} \mathrm{C}$ NMR $(100 \mathrm{MHz}$; $\mathrm{CDCl}_{3}$; ppm) $\delta_{\mathrm{C}} 161.2(\mathrm{C}-2), 158.4(\mathrm{C}-7), 152.5$ (C-9), 149.6 (C-5), 144.8 (C-2'), 139.2 (C-4), 113.1 (C-6), 112.5 (C-3), 106.4 (C-10), 105.0 (C-3'), 93.8 (C-8), and 60.1 (C-2").

Compound 16: xanthyletin. M.p.: $162.0-164.0{ }^{\circ} \mathrm{C}$. IR $\left(\mathrm{KBr}, \mathrm{cm}^{-1}\right) v_{\text {max }} 3000-2200,2900-2800,1695,1610,1550$, $1440,1360,1270,1130,1010,980$, and $815 .{ }^{1} \mathrm{H}$ NMR (400 $\left.\mathrm{MHz} ; \mathrm{CDCl}_{3} ; \mathrm{ppm}\right) \delta_{\mathrm{H}} 7.57(\mathrm{~d}, J=9.5 \mathrm{~Hz} ; \mathrm{H}-4), 7.04(\mathrm{~s}$; H-5), 6.72 (s; H-8), 6.34 (d, J= 9.9 Hz; H-4'), 6.21 (d, J=9.5 $\mathrm{Hz}$; H-3), 5.68 (d, J= 9.9 Hz; H-3'), and $1.47\left(s ; \mathrm{H}-1^{\prime \prime}\right) .{ }^{13} \mathrm{C}$ NMR (100 MHz; $\left.\mathrm{CDCl}_{3} ; \mathrm{ppm}\right) \delta_{\mathrm{C}} 161.2$ (C-2), 156.9 (C-7), 155.5 (C-9), 143.3 (C-4), 131.2 (C-3'), 124.8 (C-5), 120.8 (C-4'), 118.5 (C-6), 113.1 (C-3), 112.7 (C-10), 104.4 (C-8), 77.7 (C-2'), and 28.4 (C-1"/2").

Compound 17: (-)-marmesin. M.p.: $123.4-127.0^{\circ} \mathrm{C}$. IR $\left(\mathrm{KBr} ; \mathrm{cm}^{-1}\right) v_{\text {max }} 3400-2600,1710,1615,1555,1480,1395$, 1360, 1275, 1150, 1125, 920, 895, and 820. ${ }^{1} \mathrm{H}$ NMR (400 $\left.\mathrm{MHz} ; \mathrm{CDCl}_{3} ; \mathrm{ppm}\right) \delta_{\mathrm{H}} 7.59(\mathrm{~d}, J=9.6 \mathrm{~Hz} ; \mathrm{H}-4), 7.22(\mathrm{~s}$; H-5), 6.74 (s; H-8), 6.21 (d, J= 9.6 Hz; H-3), 4.74 (t, J= 8.9 Hz; H-2'), 3.20 (m; H-3'), 1.67 (s; OH), 1.37 (s; H-2"a), and $1.24\left(\mathrm{~s} ; \mathrm{H}-2\right.$ "b). ${ }^{13} \mathrm{C} \mathrm{NMR}\left(100 \mathrm{MHz} ; \mathrm{CDCl}_{3} ; \mathrm{ppm}\right) \delta_{\mathrm{C}}$ 163.2 (C-7), 161.4 (C-2), 156.0 (C-9), 143.7 (C-4), 125.0 (C-6), 123.4 (C-5), 112.8 (C-10), 112.3 (C-3), 91.1 (C-2'), 71.7 (C-1"), 29.5 (C-3'), 26.1 (C-2”b), and 24.3 (C-2”a).

\section{RESULTS AND DISCUSSION}

The GC chromatogram of the Group 3 in hexane showed three peaks with $\mathrm{RT}=3.42,5.45$, and $9.16 \mathrm{~min}$. MS data bank suggested structures with the respective indices of similarity given in parenthesis (1-methylpentyl)-benzene (1) (90\%), $\alpha, \alpha$-dimethyl-4-(1-methylethyl)-benzenemethanol (2) (69\%), and 1-methyl-3,5-bis(1-methylethyl)-benzene, (3) (75\%), respectively. The GC chromatogram of the Group 7 showed a peak with RT $=20.81 \mathrm{~min}$. MS data bank suggested the triterpene pentacyclic urs-12-ene (4) (68\%).

The ${ }^{1} \mathrm{H}$ NMR spectrum of the Group 8 in hexane showed several signals from $\delta_{\mathrm{H}} 5.25$ to 4.43 , which were attributed to hydrogen atoms of alkenyl and carbinolic groups. The signals at $\delta_{\mathrm{H}} 2.36$ to 0.76 were attributed to aliphatic hydrogen atoms. The ${ }^{13} \mathrm{C}$ NMR spectra and DEPT $135^{\circ}$ subspectra showed signals attributed to carbon atoms of alkenyl groups: non-hydrogenated (at $\delta_{C} 150.9,145.6,145.1$, and 139.3), mono-hydrogenated (at $\delta_{\mathrm{C}} 124.3,121.8$, and 117.6), and dihydrogenated (at $\delta_{\mathrm{C}} 109.3$ ). The signals at $\delta_{\mathrm{C}} 81.1,80.9$, and 77.6 were attributed to carbinolic carbon atoms. The intense signal at $\delta_{\mathrm{C}} 170.9$ indicated that the signals at $\delta_{\mathrm{C}} 81.1,80.9$, and 77.6 could be better attributed to acetylated carbinolic carbon atoms (Olea and Roque 1990). All these signals are characteristic of pentacyclic triterpenes (Mahato and Kundu 1994). The carbon chemical shifts recorded on the ${ }^{13} \mathrm{C}$ NMR 
spectrum (shown in Table 1) matched the values reported in the literature for triterpenes $3 \beta$-acetoxy-lup-12,20(29)-diene (5), $3 \beta$-acetoxy-olean-12-ene (6), 3 $\beta$-acetoxy-urs-12-ene (7), and adian-5-ene (8).

The GC chromatogram of the Group 11 in hexane showed six peaks $(\mathrm{RT}=24.40,25.81,26.02,28.20,29.05$, and $30.49 \mathrm{~min}$ ). The structure of chola-5,22-dien-3 $\beta$-ol (9) $(54 \%)$, cholesta-4,6-dien-3 $\beta$-ol (10) (70\%), sitosteryl $9(Z)$-octadecenoate $(\mathbf{1 1})(73 \%)$, cholesta-5,22-dien-3 $\beta$-ol (12) (69\%), and cholesta-4,6,22-trien-3-one (13) (63\%), respectively, were suggested by EIMS fragmentation data matching with Wiley library databases with the respective indices of similarity given in parenthesis. Similarly, the structure of cholesta-4,22-dien-3-one (14) (69\%) was suggested for the Group 13 in hexane ( $R T=3.62 \mathrm{~min}$ ).

Structural analysis of the Group 2 in ethanol was based on NMR data. The ${ }^{1} \mathrm{H}$ NMR spectrum showed two doublet signals at $\delta_{\mathrm{H}} 6.28(1 \mathrm{H} ; J=8.9 \mathrm{~Hz})$ and $8.16(1 \mathrm{H} ; J=8.9 \mathrm{~Hz})$. These signals were attributed to hydrogen atoms of conjugated double linking with carbonyl group. Two doublet signals at $d_{\mathrm{H}} 7.60(1 \mathrm{H} ; J=2.4 \mathrm{~Hz})$ and $7.02(1 \mathrm{H} ; J=2.4 \mathrm{~Hz})$ were also attributed to aromatic hydrogen atoms in vicinal carbons atoms. The singlet signal at $\delta_{\mathrm{H}} 7.13(1 \mathrm{H})$ was attributed to an aromatic hydrogen atom distant from the others. The singlet signal at $\delta_{\mathrm{H}} 4.30$ was attributed to the hydrogen atom of the methoxyl group. The ${ }^{13} \mathrm{C}$ NMR spectrum showed signals at $\delta_{\mathrm{C}}$ $161.2,158.4,149.6$, and 106.4, which corresponded to nonhydrogenated carbon atoms. The signals at $\delta_{\mathrm{C}} 144.8,139.2$, $112.5,105.0$, and 93.8 corresponded to mono-hydrogenated carbon atoms. The signal at $\delta_{\mathrm{C}} 60.1$ was attributed to the carbon atom of the methoxyl group. The 1D NMR spectra are characteristic of furocoumarin structures (Steck and Zazurek 1972). The ${ }^{1} \mathrm{H}-{ }^{1} \mathrm{H}$ COSY contour map showed correlations between signals at $\delta_{\mathrm{H}} 8.16(\mathrm{H}-4)$ and $6.28(\mathrm{H}-3)$, as well as between signals at $\delta_{\mathrm{H}} 7.60\left(\mathrm{H}-2^{\prime}\right)$ and $7.02\left(\mathrm{H}-3^{\prime}\right)$. The ${ }^{1} \mathrm{H}-{ }^{13} \mathrm{C}$ HMBC contour map showed correlations between the hydrogen signal at $\delta_{\mathrm{H}} 8.16(\mathrm{H}-4)$ and the carbon signals at $\delta_{\mathrm{C}} 161.2(\mathrm{C}-2)$ and $149.6(\mathrm{C}-5)$. The hydrogen signal at 7.60 $\left(\mathrm{H}-2{ }^{\prime}\right)$ correlated with carbon signals at $\delta_{\mathrm{C}} 158.4(\mathrm{C}-7)$ and 112.5 (C-6). The hydrogen signal at $d_{\mathrm{H}} 7.13(\mathrm{H}-8)$ correlated with carbon signals at $\delta_{\mathrm{C}} 158.4(\mathrm{C}-7), 112.5$ (C-6), and 106.4 (C-10). The hydrogen signal at $\delta_{\mathrm{H}} 7.02\left(\mathrm{H}-3^{\prime}\right)$ correlated with carbon signals at $\delta_{\mathrm{C}} 158.4(\mathrm{C}-7), 144.8\left(\mathrm{C}-2^{\prime}\right)$, and 112.5 (C-6). The hydrogen signal at $d_{\mathrm{H}} 6.28(\mathrm{H}-3)$ correlated with carbon signals at $\delta_{\mathrm{C}} 161.2(\mathrm{C}-2)$ and $106.4(\mathrm{C}-10)$. The hydrogen signal at $d_{\mathrm{H}} 4.30$ (H-2") correlated with a carbon signal at $\delta_{C} 149.6(\mathrm{C}-5)$, indicating the localization of the methoxyl group in the coumarinic skeleton. These HMBC correlations agree with 5-methoxypsoralen (15), a coumarin previously isolated from Brosimum acutifolium (Xavier 2001) and Brosimum gaudichaudii (Okahara 1936).
Structural analysis of the Group 5 in ethanol was based on NMR data. The ${ }^{1} \mathrm{H}$ NMR spectrum showed two doublet signals at $\delta_{\mathrm{H}} 7.57(1 \mathrm{H} ; J=9.5 \mathrm{~Hz})$ and $6.21(1 \mathrm{H} ; J=9.5$ $\mathrm{Hz}$ ). These signals were attributed to hydrogen atoms of conjugated double bond with carbonyl group. Two doublet signals at $\delta_{\mathrm{H}} 6.34(1 \mathrm{H} ; J=9.9 \mathrm{~Hz})$ and $5.68(1 \mathrm{H} ; J=9.9$ $\mathrm{Hz}$ ) were also attributed to alkenyl hydrogen atoms on vicinal carbon atoms. The singlet signals at $\delta_{\mathrm{H}} 7.04(1 \mathrm{H})$ and 6.72 were attributed to aromatic hydrogen atoms distant from others. The singlet signal at $\delta_{\mathrm{H}} 1.47(6 \mathrm{H})$ was attributed to hydrogen atoms of two methyl groups. ${ }^{13} \mathrm{C}$ NMR spectrum showed signals at $\delta_{\mathrm{C}} 161.2,156.9,155.5,118.5,112.7$, and 77.7 which corresponded to non-hydrogenated carbon atoms. The signals at $\delta_{C} 143.3,131.2,124.8,120.8,113.1$, and 104.4 corresponded to mono-hydrogenated carbon atoms. The signal at $\delta_{\mathrm{C}} 28.4$ was attributed to two carbon atoms of the methyl groups. The 1D NMR spectra are characteristic of pyrancoumarin structures (Steck and Mazurek 1972). The ${ }^{1} \mathrm{H}$ ${ }^{1} \mathrm{H}$ COSY contour map showed correlations between signals at $\delta_{\mathrm{H}} 7.57(\mathrm{H}-4)$ and $6.21(\mathrm{H}-3)$ as well as between signals at $\delta_{\mathrm{H}} 6.34\left(\mathrm{H}-4^{\prime}\right)$ and $5.68\left(\mathrm{H}-3^{3}\right)$. The ${ }^{1} \mathrm{H}^{-13} \mathrm{C}$ HMBC contour map showed correlations between the hydrogen signal at $\delta_{\mathrm{H}}$ $7.57(\mathrm{H}-4)$ and the carbon signals at $\delta_{\mathrm{C}} 161.2(\mathrm{C}-2), 155.5$ (C-9), and 124.8 (C-5). The hydrogen signal at 7.04 (H-5) correlated with the carbon signals at $\delta_{\mathrm{C}} 156.9$ (C-7), 155.5 (C-9), 143.3 (C-4), and 120.8 (C-6). The hydrogen signal at $\delta_{\mathrm{H}} 6.72(\mathrm{H}-8)$ correlated with the carbon signals at $\delta_{\mathrm{C}} 156.9$ (C-7), 155.5 (C-9), and 118.5 (C-6). The hydrogen signal at $\delta_{\mathrm{H}} 6.34\left(\mathrm{H}-4^{\prime}\right)$ correlated with carbon signals at $\delta_{\mathrm{C}} 156.9$ (C-7), 124.8 (C-5), and 77.7 (C-2'). The hydrogen signal at $\delta_{\mathrm{H}} 6.21(\mathrm{H}-3)$ correlated with the carbon signals at $\delta_{\mathrm{C}} 161.2$ $(\mathrm{C}-2)$ and $112.7(\mathrm{C}-10)$. The hydrogen signal at $\delta_{\mathrm{H}} 5.68$ $\left(\mathrm{H}-3^{\prime}\right)$ correlated with the carbon signals at $\delta_{\mathrm{C}} 118.5(\mathrm{C}-6)$, $77.7\left(\mathrm{C}-2^{\prime}\right)$, and 28.4 (C-1"/2"). The hydrogen signal at $\delta_{\mathrm{H}}$ $1.47\left(\mathrm{H}-1\right.$ "/2") correlated with the carbon signals at $\delta_{\mathrm{C}} 131.2$ (C-3') and 77.7 (C-2'). All these HMBC correlations match xanthyletin (16) (Lee et al. 2006), a coumarin previously isolated from Brosimum gaudichaudii (Okahara 1936).

Structural analysis of the Group 8 in ethanol was also based on NMR data. The ${ }^{1} \mathrm{H}$ NMR spectrum showed two doublet signals at $\delta_{\mathrm{H}} 7.60(1 \mathrm{H} ; J=9.6 \mathrm{~Hz})$ and $6.19(1 \mathrm{H} ; J$ $=9.60 \mathrm{~Hz}$ ). These signals were attributed to hydrogen atoms of conjugated double bond with carbonyl group. The triplet signal at $\delta_{\mathrm{H}} 4.72(1 \mathrm{H} ; J=8.9 \mathrm{~Hz})$ and the multiplet signal at $\delta_{\mathrm{H}} 3.19(2 \mathrm{H})$ were attributed to hydrogen atoms on vicinal carbon atoms. The other hydrogen signals, $\delta_{\mathrm{H}} 7.19$ (H-5) and $\delta_{\mathrm{H}} 6.74(\mathrm{H}-8)$, were singlet. The ${ }^{13} \mathrm{C}$ NMR spectrum showed signals at $\delta_{\mathrm{C}} 163.2,161.4,156.2,125.0,112.8$, and 71.7 corresponding to non-hydrogenated carbon atoms. The signals at $\delta_{\mathrm{C}} 143.7,123.4,112.3,98.0$, and 91.1 corresponded to mono-hydrogenated carbon atoms. The signal at $\delta_{C} 29.5$ corresponded to methylene group. The signals at $\delta_{\mathrm{C}} 26.1$ 
<smiles>CCCCC(C)c1ccccc1</smiles>

1

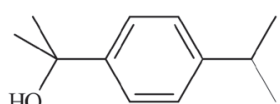

2<smiles>Cc1cc(C(C)C)cc(C(C)C)c1</smiles>

3

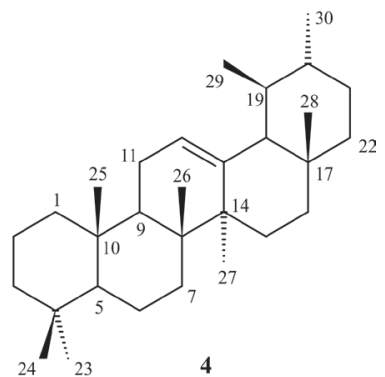<smiles></smiles><smiles>CC(=O)OC1CC[C@@]2(C)C(CCC3(C)C2CC=C2C4C[C@@H](C)CC[C@]4(C)CC[C@@]23C)C1(C)C</smiles><smiles>CC(=O)OC1CCC2(C)C(CC[C@]3(C)C2CC=C2C4C(C)[C@@H](C)CC[C@]4(C)CC[C@@]23C)C1C</smiles>

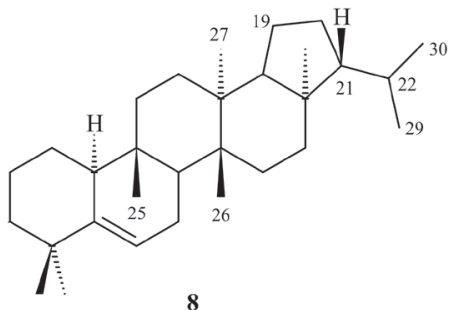<smiles>C/C=C/C(I)C1CCC2C3CC=C4CC(O)CC[C@]4(C)C3CC[C@]12C</smiles><smiles>CC(C)CCCC(C)C1CCC2C3C=CC4=CC(O)CC[C@]4(C)C3CCC12C</smiles>

10<smiles>CCCCCCCCCCCC(C)C1CCC2C3CC=C4CC(OC(=O)CCCC(C)C)CC[C@]4(C)C3CC[C@]12C</smiles><smiles>[R]C1([R])CC[C@]2(C)C(CC[C@H]3[C@@H]4CC[C@H]([C@H](C)/C=C/CC(C)C)[C@@]4(C)CC[C@H]32)C1</smiles>

12: $\mathrm{R}=\mathrm{H} ; \mathrm{R}^{\prime}=\mathrm{OH} ; \Delta^{5,6}$

13: $\mathrm{R}$ and $\mathrm{R}^{\prime}=\mathrm{O} ; \Delta^{4,5}$ and $\Delta^{6,7}$

14: $R$ and $R^{\prime}=O ; \Delta^{4,5}$<smiles>COc1c2ccoc2cc2oc(=O)ccc12</smiles>

15<smiles>CC1(F)C=Cc2cc3ccc(=O)oc3cc2O1</smiles>

16<smiles>CC(C)(O)[C@@H]1[CH]c2cc3ccc(=O)oc3cc2O1</smiles>

17

Figure 1 - Chemical structures isolated from stem of Brosimum potabile. 
and 24.3 corresponded to two methyl groups. The 1D NMR spectra are also characteristic of prenylated coumarin structures (Steck and Mazurek 1972). The ${ }^{1} \mathrm{H}^{-1} \mathrm{H}$ COSY contour map showed correlations between $\delta_{\mathrm{H}} 7.60(\mathrm{H}-4)$ and $6.19(\mathrm{H}-3)$, as well as between $\delta_{\mathrm{H}} 4.72\left(\mathrm{H}-2^{\prime}\right)$ and $3.19(\mathrm{H}-$ 3 '). The HMBC contour map showed correlations between the hydrogen signal at $\delta_{\mathrm{H}} 7.60(\mathrm{H}-4)$ and carbon signals at $\delta_{\mathrm{C}} 161.4(\mathrm{C}-2), 156.2(\mathrm{C}-9), 123.4(\mathrm{C}-5)$, and $112.8(\mathrm{C}-10)$. The hydrogen signal at $\delta_{\mathrm{H}} 7.19(\mathrm{H}-5)$ correlated with carbon signals at $\delta_{\mathrm{C}} 163.2(\mathrm{C}-7), 156.2(\mathrm{C}-9), 143.7(\mathrm{C}-4), 112.8$ $(\mathrm{C}-10)$, and $29.5\left(\mathrm{C}-3^{\prime}\right)$. The hydrogen signal at $\delta_{\mathrm{H}} 6.74(\mathrm{H}-8)$ correlated with carbon signals at $\delta_{\mathrm{C}} 163.2$ (C-7), 156.2 (C-9), $125.0(\mathrm{C}-6)$, and $112.8(\mathrm{C}-10)$. The hydrogen signal at $\delta_{\mathrm{H}}$ $6.19(\mathrm{H}-3)$ correlated with carbon signals at $\delta_{\mathrm{C}} 161.4(\mathrm{C}-2)$ and $112.80(\mathrm{C}-10)$. The hydrogen signal at $\delta_{\mathrm{H}} 4.72\left(\mathrm{H}-2^{\prime}\right)$ correlated with carbon signals at $\delta_{\mathrm{C}} 26.1(\mathrm{C}-2$ ") a) and 24.3 (C-2”b). The hydrogen signal at $\delta_{\mathrm{H}} 3.19\left(\mathrm{H}-3^{\prime}\right)$ correlated with

Table 1 - Carbon chemical shifts registered on the ${ }^{13} \mathrm{C}$ NMR spectra of $\mathbf{8}, \mathbf{9}, \mathbf{1 0}$ and 11 and corresponding values (in parenthesis) registered in the literature (Mahato and Kundu 1994)

\begin{tabular}{|c|c|c|c|c|}
\hline \multirow{2}{*}{ Carbon } & \multicolumn{4}{|c|}{ Pentacyclic triterpene } \\
\hline & 8 & 9 & 10 & 11 \\
\hline C-1 & $38.3(38.7)$ & $38.3(38.7)$ & $38.3(38.7)$ & $23.6(23.8)$ \\
\hline$C-2$ & $27.5(27.4)$ & $27.4(27.3)$ & $27.2(27.2)$ & $22.0(21.9)$ \\
\hline C-3 & $80.9(78.9)$ & $81.1(79.0)$ & $80.6(78.3)$ & $40.8(40.9)$ \\
\hline C-4 & 39.5 (38.8) & $38.5(38.8)$ & $38.2(38.7)$ & $34.7(34.8)$ \\
\hline C-5 & $55.3(55.3)$ & $55.3(55.3)$ & $55.2(55.2)$ & $145.9(145.6)$ \\
\hline C-6 & $18.1(18.3)$ & $18.3(18.5)$ & $18.1(18.3)$ & $117.5(117.6)$ \\
\hline C-7 & $34.1(34.2)$ & $32.8(32.8)$ & $32.8(32.9)$ & $34.1(34.3)$ \\
\hline C-8 & $40.8(40.8)$ & $38.2(38.8)$ & $39.9(40.0)$ & $51.5(51.8)$ \\
\hline C-9 & $50.3(50.4)$ & $47.6(47.7)$ & $47.5(47.7)$ & $35.5(35.7)$ \\
\hline C-10 & $37.0(37.1)$ & $37.7(37.6)$ & $36.9(36.9)$ & $43,4(44.3)$ \\
\hline C-11 & $20.9(20.9)$ & $23.5(23.6)$ & $23.3(23.3)$ & $25.9(25.9)$ \\
\hline C-12 & $25.0(25.1)$ & $121.6(121.8)$ & $124.2(124.3)$ & $29.2(29.2)$ \\
\hline C-13 & $38.0(38.0)$ & $145.1(145.1)$ & $139.5(139.3)$ & $38.5(38.7)$ \\
\hline C-14 & $42.7(42.8)$ & $41.6(41.8)$ & $42.0(42.0)$ & $39.5(39.4)$ \\
\hline C-15 & $27.5(27.4)$ & $26.1(26.2)$ & $28.7(28.7)$ & $29.7(29.2)$ \\
\hline C-16 & $35.5(35.5)$ & $27.0(27.0)$ & $26.5(26.6)$ & $35.5(35.5)$ \\
\hline $\mathrm{C}-17$ & $42.9(43.0)$ & $32.4(32.5)$ & $33.7(33.7)$ & $42,3(42.9)$ \\
\hline C-18 & $48.2(48.2)$ & $47.2(47.4)$ & $59.0(58.9)$ & $52.9(52.9)$ \\
\hline C-19 & $47.9(47.9)$ & $46.8(46.9)$ & 39.7 (39.6) & $20.9(20.8)$ \\
\hline C-20 & $150.7(150.9)$ & $31.0(31.1)$ & 39.7 (39.6) & $28.3(28.4)$ \\
\hline C-21 & $29.6(29.8)$ & 34.7 (34.8) & $30.9(31.2)$ & $59.8(60.1)$ \\
\hline C-22 & $39.9(40.0)$ & 37.6 (37.2) & $41.5(41.5)$ & $30.9(30.8)$ \\
\hline C-23 & $28.0(28.0)$ & 28.1 (28.2) & $28.1(28.1)$ & $29.8(30.0)$ \\
\hline C-24 & $15.5(15.4)$ & $15.7(15.5)$ & $15.8(15.6)$ & $29.8(29.8)$ \\
\hline C-25 & $16.1(16.1)$ & $15.8(15.6)$ & $15.7(15.6)$ & $16.4(16.1)$ \\
\hline C-26 & $15.9(15.9)$ & $16.7(16.9)$ & $16.8(16.8)$ & $17.6(17.9)$ \\
\hline $\mathrm{C}-27$ & $14.4(14.5)$ & $25.7(26.0)$ & $23.2(23.3)$ & $15.4(15.1)$ \\
\hline C-28 & $17.9(18.0)$ & $28.3(28.4)$ & $27.9(28.1)$ & $15.8(15.8)$ \\
\hline C-29 & $109.3(109.3)$ & 33.5 (33.3) & $17.4(17.4)$ & $21.8(22.0)$ \\
\hline$C-30$ & $19.2(19.3)$ & $23.9(23.7)$ & $21.3(21.3)$ & $22.6(22.9)$ \\
\hline
\end{tabular}

carbon signals at $\delta_{\mathrm{C}} 163.2(\mathrm{C}-7), 125.0(\mathrm{C}-6), 123.4(\mathrm{C}-5)$, $91.1\left(\mathrm{C}-2^{\prime}\right)$, and $71.7\left(\mathrm{C}-1\right.$ "). The hydrogen signals at $\delta_{\mathrm{H}} 1.36$ (H-2"b) and 1.22 (H-2"a) correlated with carbon signals at $\delta_{\mathrm{C}} 91.1\left(\mathrm{C}-2^{\prime}\right), 71.7$ (C-1"), 26.1 (C-2"a), and 24.3 (C-2"b). All these HMBC correlations agree with (-)-marmesin (17) (Liu et al. 2005), a prenylated coumarin previously isolated from Brosimum gaudichaudii (Okahara 1936).

\section{ACKNOWLEDGEMENTS}

The authors thank Conselho Nacional de Desenvolvimento Científico e Tecnológico (CNPq), Fundação Coordenação de Aperfeiçoamento de Pessoal de Nível Superior (CAPES), Fundaçáo de Amparo à Pesquisa do Estado de Minas Gerais (FAPEMIG), and Fundação de Amparo à Pesquisa do Estado do Amazonas (FAPEAM) for the financial support.

\section{LITERATURE CITED}

Alcântara, A.F.C.; Souza, M.R.; Piló-Veloso, D. 2000. Constituents of Brosimum potabile. Fitoterapia, 71: 613-615.

Barroso, M.G. 1978. Sistemática de Angiospermas do Brasil. Livros Técnicos e Científicos, São Paulo, Brasil, 200 pp.

Berg, C.C. 1972. Brosimeae (Moraceae) in Flora Neotropica 7: 161225.

Braz Filho, R.; Magalhães, A.F.; Gottlieb, O.R. 1972. Coumarins from [the heartwood of] Brosimum rubescens: Chemistry of Brazilian Moraceae, Part 3. Phytochemistry, 11: 3307-3310.

Garret, R.H.; Grishan, C.M. 1988. Biochemistry. Saunders College Publishing, Orlando, USA, 300 pp.

Gottlieb, O.R.; Silva, M.L.; Maia, J.G.S. 1972. Distribution of coumarins in Amazonian Brosimum species. Phytochemistry, 11: 3479-3480

Shin, B.-K.; Kim, H.M.; Lee, S.; Han, J. 2008. Axial Conformation of 3-Methyl-2-butenoyl Group in Pyranocoumarin Ring Endows Biological Activity of (+)-Decursin. Bulletin of the Korean Chemical Society, 29: 1572-1574.

Liu, R.; Sun, Q.; Shi, Y.; Kong, L. 2005. Isolation and purification of coumarin compounds from the root of Peucedanum decursivum (Miq.) Maxim by high-speed counter-current chromatography. Journal of Chromatography A, 1076: 127-132.

Mahato, S.B.; Kundu, A.P. $1994 .{ }^{13} \mathrm{C}$ NMR spectra of pentacyclic triterpenoids - a compilation and some salient features. Phytochemistry, 37: 1517-1575.

Okahara, K. 1936. Studies on the Chemical Constituents of the Leaves of Ficus microcarpa Linn. Bulletin of the Chemical Society of Japan, 11: 389-394.

Olea, R.S.G; Roque, N.F. 1990. Análise de misturas de triterpenos por RMN de ${ }^{13}$ C. Química Nova, 13: 278-281.

Oliveira, A.N.; Amaral, I.L. 2004. Florística e fitossociologia de uma floresta de vertente na Amazônia Central, Amazonas, Brasil. Acta Amazonica, 34: 21-34. 
Pio Correia, M. 1978. Dicionário de Plantas Úteis do Brasil e das Exóticas Cultivadas. Ministério da Agricultura, IBDF, Imprensa Nacional, Rio de Janeiro, Brasil, 500 pp.

Schultes, R.E.; Foreword, R.F.R. 1992. Medicinal and Toxic Plants of the Northwest Amazonia. Dioscorides Press, Portland, USA, 250 pp.

Steck, W.; Mazurek, M. 1972. Identification of Natural Coumarins by NMR Spectroscopy. Lloydia, 35: 418-439,

Teixeira, A.F.; Alcântara, A.F.C.; Piló-Veloso, D. 2000. Structure determination by ${ }^{1} \mathrm{H}$ and ${ }^{13} \mathrm{C}$ NMR of a new flavan isolated from Brosimum acutifolium: 4',7-dihydroxy-8-prenylflavan. Magnetic Resonance in Chemistry, 38: 301-304.
Torres, S.L.; Moneiro, J.C.M.; Arruda, M.S.P.; Müller, A.H.; Arruda, A.C.; 1997. Two flavans from Brosimum acutifolium. Phytochemistry, 44: 347-349.

Xavier, I.F.S. 2001. Estudo Fitoquímico do Caule de Brosimum acutifolium. Dissertação de Mestrado, Universidade Federal do Amazonas, Manaus, Amazonas. 184 pp.

Recebido em 27/01/2010

Aceito em 06/02/2010 
